\title{
Comments to Paper Entitled: Development of a Data-Driven Predictive Model of Supply Air Temperature in an Air-Handling Unit for Conserving Energy. Energies 2018, 11, 407
}

\author{
Yaolin Lin ${ }^{1, *(1)}$ and Wei Yang ${ }^{2}$ \\ 1 School of Civil Engineering and Architecture, Wuhan University of Technology, Wuhan 430070, China \\ 2 College of Engineering and Science, Victoria University, Melbourne 8001, Australia; Wei.Yang@vu.edu.au \\ * Correspondence: yaolinlin@gmail.com
}

Received: 15 March 2018; Accepted: 22 May 2018; Published: 4 June 2018

check for updates

I have read, with interest, the article authorized by Hong and Kim, which was published in Energies 2018, 11, 407; doi:10.3390/en11020407: entitled “Development of a Data-Driven Predictive Model of Supply Air Temperature in an Air-Handling Unit for Conserving Energy" [1]. I have some concerns about their study approach.

The first concern is that the authors selected outside air temperature, supply air temperature, return air temperature, mixed air temperature, and time related variables as inputs to the models. However, the authors neglected that there is a supply air temperature (SAT) set point, which is conventionally based on outside air temperature [2], which is also the current best practice as proposed by ASHRAE GPC 36. The optimized SAT set point could also be a function of outside air temperature, outside air relative humidity, outdoor air flow rate and supply air flow rate [3], outside air temperature, minimum reheat valve position or return air temperature [4], outside air temperature, load ratio and power exponents [5], outside air temperature and total number of people [2], energy cost signal, and cooling demand [6]. If properly tuned, the SAT should be able to meet its set point. However, the SAT set point reset strategy in this paper is missing.

The second concern is that this paper aims at predicting SAT for energy conservation, however, the energy consumption under different SAT reset strategies is missing.

In order to find optimal SAT control for energy conservation purpose, data mining on the association various SAT controls and related energy consumption is needed.

Conflicts of Interest: The authors declare no conflict of interest.

\section{References}

1. Hong, G.; Kim, B.S. Development of a Data-Driven Predictive Model of Supply Air Temperature in an Air-Handling Unit for Conserving Energy. Energies 2018, 11, 407. [CrossRef]

2. Gruber, M.; Trüschel, A.; Dalenbäck, J.-O. Alternative strategies for supply air temperature control in office buildings. Energy Build. 2014, 82, 406-415. [CrossRef]

3. Ke, Y.; Mumma, S.A. Optimized supply-air temperature (SAT) in variable-air-volume (VAV) systems. Energy 1997, 22, 601-614. [CrossRef]

4. Liu, M.; Claridge, D.E.; Turner, W.D. Continuous commissioning SM guidebook: maximizing building energy efficiency and comfort. In Federal Energy Management Program; U.S. Department of Energy: Washington, DC, USA, 2002. 
5. Wang, G.; Song, L. Air handling unit supply air temperature optimal control during economizer cycles. Energy Build. 2012, 49, 310-316. [CrossRef]

6. Raftery, P.; Li, S.; Jin, B.; Ting, M.; Paliaga, G.; Cheng, H. Evaluation of a cost-responsive supply air temperature reset strategy in an office building. Energy Build. 2018, 158, 356-370. [CrossRef] 